\title{
Pemikiran Inklusif Atas Dampak Pembangunan Terhadap Kelestarian Sumberdaya Arkeologi
}

\section{Baskoro Daru Tjahjono}

Keywords: cultural resource management, method, conservation, theory, heritage

\section{How to Cite:}

Tjahjono, B. D. Pemikiran Inklusif Atas Dampak Pembangunan Terhadap Kelestarian Sumberdaya Arkeologi. Berkala Arkeologi, 16(1), 40-48. https://doi.org/10.30883/jba.v16i1.745

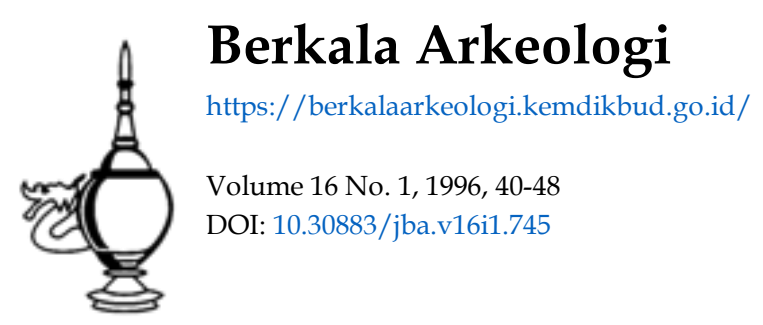

\section{c) (7) (2)}

This work is licensed under a Creative Commons Attribution-NonCommercial-ShareAlike 4.0 International License. 


\author{
Baskoro D. Tjahjono \\ (Balai Arkeologi Yogyakarta)
}

\title{
1. Pendahuluan
}

Bangsa Indonesia saat ini sedang giat-giatnya melakukan pembangunan di segala bidang. Program pembangunan di Indonesia yang dilaksanakan secara terencana dan bertahap saat ini telah memasuki PJP II. Pembangunan itu sendiri merupakan upaya untuk memajukan kehidupan ekonomi dan teknologi untuk membentuk masa depan yang lebih baik bagi bangsa, masyarakat, dan negara. Pembangunan nasional yang sedang digalakkan ini sesungguhnya tidak hanya untuk meningkatkan sumberdaya fisik berupa bahan pangan, sandang, perumahan, ruang dan peralatan kerja, serta sarana dan perhubungan dan komunikasi yang dapat dimanfaatkan oleh bangsa kita dalam kehidupan masa kini dan masa depan, melainkan meliputi juga upaya untuk mengembangkan kebudayaan nasional (Bachtiar, 1989:68)

Dengan demikian pembangunan di segala bidang itu meliputi berbagai sektor, seperti: iptek, ideologi, sosial, budaya, politik, dan hankam. Khusus pembangunan di bidang kebudayaan adalah termasuk pengelolaan sumberdaya arkeologi atau dalam UU RI No. 5 tahun 1992 disebut Benda Cagar Budaya (BCB) dan situsnya. Untuk menunjang keberhasilan pembangunan itu segala sumberdaya yang ada harus dimanfaatkan dan dikelola dengan serasi, seimbang, dan selaras untuk kemanfaatan masyarakat dalam arti luas. Sumberdaya itu meliputi sumberdaya manusia, sumberdaya alam, sumberdaya buatan, dan sumberdaya budaya (arkeologi) (Kusumohartono, 1995:5) Semuanya itu ditujukan untuk mencapai cita-cita masyarakat adil dan makmur, serta untuk dapat mensejajarkan diri dengan bangsa-bangsa lain yang sudah maju. Dalam kenyataannya dari berbagai bidang pembangunan tersebut prioritas utama pembangunan masih berkisar pada pembangunan bidang prasarana fisik yang menekankan peningkatan ekonomi.

Dalam kenyataannya pula, upaya pelestarian sumberdaya arkeologi sering berbenturan dengan pembangunan di bidang prasarana fisik tersebut. Pembangunan bidang prasarana fisik sering berdampak negatif bagi upaya pelestarian sumberdaya arkeologi. Rencana pe- 
ngembangan kota atau wilayah masih sering mengabaikan keberadaan sumberdaya arkeologi, pendirian pabrik-pabrik, pembangunan waduk, pembangunan jalan tol seringkali terpaksa menghancurkan, memusnahkan, atau menenggelamkan sumberdaya arkeologi yang ada. Dengan demikian dampak pembangunan sering dipandang negatif bagi perkembangan arkeologi di masa datang, karena menghilangkan data arkeologi. Masalahnya sekarang, apakah tidak ada segi positif dari dampak pembangunan itu bagi perkembangan arkeologi di masa datang? Di lain pihak upaya pelestarian sumberdaya arkeologi sering dipandang sebagai kegiatan yang tidak relevan dengan perkembangan zaman, kegiatan yang tidak mempunyai prospek di bidang ekonomi dan tidak langsung memberi kesejahteraan bagi rakyat. Jadi seolah-olah antara kegiatan pembangunan dan pelestarian sumberdaya arkeologi merupakan dua kepentingan yang saling bertentangan, kegiatan pembangunan berorientasi ke masa depan sedangkan upaya pelestarian sumberdaya arkeologi berorientasi ke masa lalu. Dalam pemikiran lama yang bersifat antagonistis atau eksklusif maka akan terjadi pemikiran bahwa pihaknyalah yang paling penting, di satu pihak akan beranggapan bahwa pembangunan lebih penting, sedangkan pihak lain akan mengatakan bahwa pelestarian sumberdaya arkeologi sangat penting dan mendesak untuk diprioritaskan.

Pemikiran inklusif mengajak masing-masing pihak yang "bertentangan" dapat menempatkan dirinya pada pihak yang lain. Bahwa kepentingan pihak yang lain sebenarnya juga merupakan kepentingan pihaknya sendiri (Boerwinkel:1973,28-29). Pembangunan tidak dapat mengabaikan pelestarian sumberdaya arkeologi, demikian sebaliknya pelestarian sumberdaya arkeologi tidak dapat dipisahkan dari pembangunan yang berwawasan lingkungan. Dengan demikian pemikiran inklusif akan melihat segi positif dari dampak pembangunan itu bagi perkembangan arkeolog: di masa datang.

\section{Pembangunan dan Pentingnya Pelestarian Sumberdaya Arkeologi}

Pembangunan di Indonesia saat ini telah memasuki Pelita VI, yang berarti pula memasuki tahapan pertama Pembangunan Jangka Panjang 25 tahun kedua. Bahkan sebentar lagi akan memasuki Repelita VII. Tahapan ini mempunyai arti khusus dan strategis karena merupakan tahapan untuk mempersiapkan proses tinggal landas pembangunan nasional sebagai pengamalan Pancasila (GBHN 1993. 1998, 1-2). Pembangunan nasional merupakan rangkaian upaya pembangunan yang berkesinambungan yang meliputi seluruh 
kehidupan masyarakat, bangsa, dan negara untuk melaksanakan tugas mewujudkan tujuan nasional yang termaktub dalam Pembukaan Undang-undang Dasar 1945, yaitu melindungi segenap bangsa dan seluruh tumpah darah Indonesia, memajukan kesejahteraan umum, mencerdaskan kehidupan bangsa, serta ikut melaksanakan ketertiban dunia yang berdasarkan kemerdekaan, perdamaian abadi, dan keadilan sosial (GBHN 1993-1998, 7). Pembukaan UUD 1945 itu merupakan sendi-sendi yang paling dasar dari cita-cita bangsa Indonesia, dimana aturan main untuk mencapai cita-cita tersebut diatur melalui Batang Tubuh UUD 1945 (Abbas dkk., 1995:1). Berdasarkan hal itu maka arah pembangunan di setiap sektor, termasuk di dalamnya sektor kebudayaan berorientasi pada sendi-sendi dasar tersebut.

Sumberdaya arkeologi atau Benda Cagar Budaya beserta situsnya adalah sisa-sisa hasil budaya fisik peninggalan nenek moyang yang masih dapat dilihat di muka bumi sampai saat ini. Sumberdaya arkeologi tersebut merupakan warisan budaya dan merupakan data yang sangat penting untuk rekonstruksi sejarah serta mengetahui proses perubahan budaya masa lalu. Scovil, Gordon, dan Anderson (1977) mengatakan bahwa sumberdaya arkeologi adalah semua bukti fisik atau sisa budaya yang ditinggalkan oleh manusia masa lampau pada bentang alam tertentu yang berguna untuk meng-gambarkan, menjelaskan, serta memahami tingkah laku dan interaksi mereka sebagai bagian yang tidak dapat dipisahkan dari perubahan sistem budaya dan alamnya (lbid., 5). Sumberdaya arkeologi tersebut merupakan bukti otentik yang menghubungkan masa lalu dengan masa kini, dengan demikian diperlukan pengelolaan yang seksama agar dapat dimanfaatkan secara optimal dan bijaksana. Pengelolaan sumberdaya arkeologi tersebut di Indonesia diatur dalam Undangundang Rl Nomor 5 Tahun 1992 tentang Benda Cagar Budaya. Sumberdaya arkeologi tersebut dapat dimanfaatkan dan dikembangkan bagi kepentingan berbagai sektor pembangunan. Hal ini selaras dengan amanat TAP MPR-RI No. II/MPR/1993 tentang GBHN 19931998, yang mendorong dikembang-kannya sumberdaya budaya bagi kepentingan yang seluas-luasnya (Anonim, 1995b: 1-2).

Sumberdaya arkeologi sering juga disebut sebagai sumberdaya budaya mati, yang mempunyai sifat terbatas (finite), tak terperbarui (nonrenewable), tak dapat dipindahkan (nonmoveble), dan mudah rapuh (vuinerableffragile) (Drajad, 1995: 3). Karena sifat-sifatnya itu, jika tidak dikelola dengan baik dan benar, sumberdaya arkeologi tersebut akan menurun kualitasnya bahkan akan musnah akibat ulah manusia atau pengaruh alam. Pengelolaan sumberdaya arkeologi tersebut merupakan bagian dari manajemen sumberdaya arkeologi. 
Rangkaian manajemen sumberdaya arkeologi meliputi penelitian, pelestarian, pembinaan, dan pemanfaatan. Penelitian arkeologi merupakan kegiatan hulu, sedangkan pelestarian, pembinaan, dan pemanfaatan merupakan kegiatan hilinya, artinya penelitian diselenggarakan pada bagian awal untuk memberi masukan dan pertimbangan sekaligus acuan bagi kegiatan hilirnya (Ibid, 1-2)

Di antara ketiga kegiatan hilir, pelestarian merupakan kegiatan yang penting dan utama, sebab tanpa pelestarian maka kegiatan pembinaan dan pemanfaatan tidak dapat dilaksanakan. Sumberdaya arkeologi merupakan data arkeologi yang sangat penting, oleh karena itu upaya penyelamatan data atau pelestarian sumberdaya arkeologi perlu mendapat perhatian utama untuk dikembangkan dan dimasyarakatkan (Kusumohartono,4993:46). Pentingnya upaya pelestarian sumberdaya arkeologi ini juga telah dikemukakan oleh Mundarjito. Dikatakan bahwa pelestarian budaya sepatutnya lebih banyak dimasyarakatkan, karena pada dasarnya para arkeolog dalam menunaikan tugasnya sangat tergantung kepada data yang pada hakekatnya amat terbatas. Keterbatasan data itulah yang menyebabkan para peneliti harus sekaligus mengupayakan pelestarian terhadap data yang ditelitinya. Peneliti yang bertugas merakit himpunan data masa lalu yang tercecer itu tidak dapat memenuhi tugasnya dengan baik dan berkelanjutan jika sumberdaya arkeologi yang menjadi objek penelitiannya itu tidak lestari (Mundarjito, 1996: 124).

\section{Dampak Pembangunan terhadap Kelestarian Sumberdaya Arkeologi}

Jika pelaksanaan pembangunan selalu mengacu kepada amanat pembukaan Undang-undang Dasar 1945 tentu tidak akan terjadi konflik dengan kepentingan pelestarian sumberdaya arkeologi Sebab pembangunan yang diharapkan dan dicita-citakan adalah pembangunan di segala sektor termasuk di dalamnya untuk memajukan kebudayaan nasional. Namun di dalam kenyataannya pembangunan yang sedang digalakkan mașih menitikberatkan pada pengembangan di bidang ekonomi, sehingga sektor kebudayaan yang dianggap tidak langsung memberikan kesejahteraan bagi rakyat cenderung terabaikan. Lebihlebih lagi upaya pelestarian terhadap sumberdaya arkeologi yang dianggap kurang berorientasi ke masa depan kurang mendapat porsi pembangunan yang proporsional. Bahkan pembangunar fisik yang sedang giat-giatnya dilaksanakan cenderung berdampak negatif bagi keberadaan sumberdaya arkeologi yang dilintasi oleh proyek-proyek pembangunan. Dalam era industri semakin banyak kegiatan pembangunan fisik dan penggunaan lahan yang dapat menghancurkan, 
mengalihfungsikan, dan menenggelamkan situs (Hutt, Jones dan Mc Allister, 1992; Mundarjito,1996:130). Banyak situs yang sudah ditemukan akan rusak atau hancur, banyak situs yang belum diteliti atau belum diketahui tidak sempat diteliti, atau situs yang baru akan lahir mengalami abortus (Mundarjito, 1996: 130).

Proyek-proyek pembangunan yang berdampak negatif bagi pelestarian sumberdaya arkeologi, misalnya:

a. Rencana pelebaran jalan arteri di dalam Kota Gresik akan berpengaruh terhadap kelestarian rumah-rumah tradisional dan bangunan berarsitektur kuna (Abbas, 1995: 41).

b. Penetapan kawasan industri di wilayah Kecamatan Manyar Kabupaten Gresik mengakibatkan munculnya pabrik-pabrik di sekitar situs Kompleks Makam Leran. Dampak yang muncul akibat pembangunan pabrik adalah penurunan tanah di sekitar situs akibat penam-bangan tanah untuk peninggian pabrik dapat menyebabkan erosi pada areal situs (lbid.: 55).

c. Rencana jalan tol Solo - Yogyakarta dikawatirkan akan mereduksi situs-situs arkeologi yang tersebar di sepanjang jalur yang akan dilalui jalan tol tersebut.

d. Pembangunan waduk Gajahmungkur di Wonogiri telah menenggelamkan situs candi Bendo, walaupun sebelumnya telah dilakukan penelitian terhadap candi tersebut

e. Demikian pula pembangunan waduk Kedung Ombo Jawa Tengah juga menenggelamkan situs-situs dari masa Prasejarah sampai masa Islam (Indraningsih, 1985).

Sederet contoh kurban-kurban pembangunan fisik terhadap kelestarian sumberdaya arkeologi juga telah dipaparkan oleh Mundarjito dalam Pidato Pengukuhan Gurubesar Madya Tetap pada Fakultas Sastra Universitas Indonesia, tanggal 7 Oktober 1995 dan ditulis dalam Jurnal Arkeologi Indonesia Nomor 2/ Maret 1996 (Mundarjito, 1996:128. 130). Dan masih banyak lagi kegiatan pembangunan yang cenderung mengurbankan keberadaan sumberdaya arkeologi, yang tertulis di atas hanyalah beberapa contoh saja.

Sebenarnya tidak hanya pembangunan fisik seperti tersebut di atas saja yang dapat mengakibatkan menurunnya kualitas sumberdaya arkeologi. Pembangunan yang berkaitan langsung dengan eksploitasi sumberdaya arkeologi, seperti penelitian, pelestarian, pembinaan, dan pemanfaatan pun dapat berakibat menurunnya kualitas sumberdaya arkeologi apabila salah dalam penerapannya. Sebagai contoh pembangunan fasilitas pariwisata untuk pengembargan situs Kraton Ratu Boko telah mengakibatkan kerusakan pada beberapa bagian situs, seperti rusaknya jalan asli ke arah pintu gerbang. Demikian juga 
pemugaran candi Ceta di lereng Gunung Lawu yang menyalahi prinsipprinsip arkeologi, dan juga pemugaran makam-makam kuna dengan menggunakan bahan-bahan baru berakibat menurunnya kualitas situs.

Selain itu juga banyaknya sumberdaya arkeologi yang tersebar di seluruh pelosok Tanah Air ini belum mampu dikelola dengan baik oleh instansi yang berwenang karena keterbatasan tenaga maupun dana Sehingga banyak sumberdaya arkeologi yang terbengkelai dan tidak terawat, yang akhirnya akan musnah oleh pengaruh alam ataupun ulah manusia. Mengingat keterbatasan tersebut maka beberapa upaya telah dilakukan untuk dapat mengelola sumberdaya arkeologi tersebut berdasarkan skala prioritas. Penentuan skala prioritas tersebut didasarkan pada analisis potensi dan permasalahannya.

Potensi data dan kualitas sumberdaya arkeologi sangat menentukan nilai penting suatu situs arkeologi. Potensi data yang dimaksudkan adalah kemampuan data yang terakumulasi dari suatu situs untuk dapat dimanfaatkan bagi berbagai kepentingan. Analisis terhadap potensi sumberdaya arkeologi dapat dijabarkan melalui empat aspek nilai penting sebagai berikut:

a. Aspek kesejarahan: sejauh mana sumberdaya arkeologi dilatarbelakangi oleh peristiwa bersejarah yang dianggap penting serta yang berkaitan secara simbolis dengan peristiwa terdahulu.

b. Aspek ilmu pengetahuan: sejauh mana sumberdaya arkeologi memiliki deposit mutu serta keluasan dalam pengembangan ilmu pengetahuan.

c. Aspek kebudayaan: sejauh mana peran penting sumberdaya arkeologi dalam suatu kelompok masyarakat, terutama berkaitan dengan tradisi, kesenian, maupun kepercayaan setempat.

d. Aspek sosial ekonomi: sejauh mana peran penting sumberdaya arkeologi bagi aspek-aspek nilai dan kehidupan masyarakat, misalnya pendidikan, jati diri, dan citra kawasan. Selain itu sejauh mana akses maupun nilai komersial sumberdaya arkeologi dalam meningkatkan pendapatan ekonomis bagi suatu tempat, misalnya pariwisata. (Abbas, 1995: 45-46).

Sedangkan analisis permasalahan adalah untuk mengetahui besar kecilnya dampak terhadap sumberdaya arkeologi. Permasalahan dapat berupa penurunan nilai, rusak, bahkan melenyapkan sama sekali keberadaan situs.

Dengan diketahuinya potensi serta permasalahannya maka dapat ditentukan pula prioritas pengelolaan situs atau sumberdaya arkeologi yang ada. Tidak semua sumberdaya arkeologi harus dipertahankan keberadaannya apabila terkena dampak pembangunan, ini tergantung dari nilai penting dan permasalahannya. Jika sumberdaya arkeologi 
yang terdapat di lokasi proyek pembangunan mempunyai nilai penting yang sangat tinggi, maka harus dipertahankan dengan kebijakan tersendiri. Akan tetapi apabila sumberdaya arkeologi tersebut mempunyai nilai yang relatif rendah, maka cukup diselamatkan dengan pendokumentasian.

\section{Pemikiran Inklusif atas Dampak Pembangunan terhadap Kelesta- rian Sumberdaya Arkeologi}

Kita selalu mengharapkan yang ideal baik terhadap pelaksanaan pembangunan maupun dalam pengelolaan sumberdaya arkeologi Namun kenyataan di lapangan harapan ideal tersebut tidak selalu dapat terlaksana, bahkan sebaliknya hal yang terburuklah yang terjadi Pembangunan tidak selalu menghasilkan dampak yang positif, seringkali pembangunan berdampak negatif bagi upaya pelestarian sumberdaya arkeologi.

Jika demikian kita harus mulai berfikir inklusif, bahwa dampak yang terburuk sekalipun terhadap pelestarian sumberdaya arkeologi masih bermanfaat bagi perkembangan dunia arkeologi pada khususnya dan bagi masyarakat pada umumnya. Kita harus berfikir bahwa setiap perkembangan zaman selalu terjadi perubahanperubahan, baik fisik maupun non-fisik. Dan merupakan hal yang wajar jika pembangunan dewasa ini juga menghasilkan perubahanperubahan, bahkan terpaksa harus memusnahkan sesuatu yang sudah ada diganti dengan sesuatu yang baru.

Kita tidak bisa mengharapkan bahwa pembangunan harus dilakukan di kawasan yang belum digunakan sama sekali atau membuka lahan baru untuk perkotaan baru. Jika itu terjadi, tentu juga akan menimbulkan dampak baik positif maupun negatif bagi wilayah yang baru dikembangkan itu. Jadi kita tidak bisa lepas dari dampak, dampak hanya bisa dikurangi. Pembangunan pada umumnya mengembangkan kawasan perkotaan atau desa-desa yang sudah ada, bisa memperluas kawasan yang sudah ada atau mengembangkannya agar lebih modern. Tentu saja akan terjadi konflik kepentingan antara yang ingin mempertahankan keadaan semula dengan yang menginginkan pengembangan suatu kawasan. Mungkin kawasan itu adalah kawasan kumuh yang di dalamnya terdapat situs yang terbengkelai karena tidak/belum dikelola dengan baik, agar tampak tidak kumuh dan modern maka kawasan tersebut akan dikembangkan menjadi pusat pertokoan atau kompleks perumahan. Tujuan pembangunan kawasan itu baik tetapi pasti akan menimbulkan konflik kepentingan dengan upaya pelestarian sumberdaya arkeologi yang ada di kawasan itu 
Jika kita mau berfikir inklusif, perubahan, perusakan, ataupun pemusnahan sumberdaya arkeologi yang sering terjadi akibat derap pembangunan yang begitu cepat, sebenarnya masih ada manfaatnya bagi perkembangan arkeologi di masa datang. Bukankah ini merupakan satu kasus bagi arkeolog masa depan bahwa pada abad $X X$ telah terjadi perubahan besar, kota ataupun desa telah mengalami perkembangan pesat dan telah terjadi modernisasi di segala bidang. sehingga hal-hal yang dianggap kuna termasuk di dalamnya sumberdaya arkeologi dimusnahkan. Keadaan tersebut dapat diangkat sebagai tema-tema baru dalam perkembangan arkeologi masa mendatang. Bukankah arkeologi tidak hanya berhenti sampai masa Prasejarah, atau masa Klasik, atau masa Islam saja. Arkeologi akan terus berkembang mengikuti zamannya. Data arkeologi juga akan lebih bervariasi lagi, jalan tol, waduk, atau benda-benda yang ada sekarang, akan menjadi data arkeologi bagi para arkeolog masa yang akan datang. Hal ini sebenarnya sama dengan zaman-zaman sebelumnya, perubahan dari masa Prasejarah ke masa Klasik, atau dari masa Klasik ke masa Islam, dari masa Islam ke masa Kolonial, sampai sekarang ini pasti terjadi perubahan-perubahan di berbagai bidang yang mungkin juga diikuti dengan penggusuran-penggusuran atau perusakan-perusakan terhadap situs-situs yang ada sebelumnya karena dianggap tidak sesuai dengan zamannya.

Namun yang paling ideal adalah masing-masing pihak harus mau berfikir secara inklusif. Pembangunan tidak dapat mengabaikan pelestarian sumberdaya arkeologi, demikian sebaliknya pelestarian sumberdaya arkeologi tidak dapat dipisahkan dari pembangunan yang berwawasan lingkungan.

\section{Kepustakaan}

Abbas, Novida dkk (ed.), 1995. Penelitian Arkeologi Kota di Gresik, Jawa Timur, Jurnal Penelitian Arkeologi No. 02-TH 1/1995, Pusat Penelitian Arkeologi Nasional, Balai Arkeologi Yogyakarta, Bagian Proyek Penelitian Purbakala D I Yogyakarta.

Anonim, 1995a Studi Perencanaan Pengembangan Tempat-tempat
Benda Bersejarah dan Purbakala di Kabupaten Tulungagung.
Provinsi Jawa Timur (Laporan Akhir) Balai Arkeologi Yogyakarta 
Anonim, 1995b. Studi Perencanaan Pengembangan Tempat-tempat Benda Bersejarah dan Purbakala di Kabupaten Lumajang, Provinsi Jawa Timur (Laporan Akhir), Balai Arkeologi Yogyakarta

Bachtiar, Harsja W.,1989. Arkeologi dan Pembangunan Budaya, Pertemuan IImiah Arkeologi V. Yogyakarta 4.7 Juli 1989.

Boerwinkel,Feitse, 1973, Berfikir Inklusif, terjemahan Suryadi, Jakarta

Dradjad, Hari Untoro, 1995, Manajemen Sumberdaya Budaya Mati, Seminar Nasional Metodologi Riset Arkeologi, Depok, 23-24 Januari 1995, Jurusan Arkeologi Fakultas Sastra Universitas Indonesia

Garis-garis Besar Haluan Negara 1993-1998 (Tap. MPR Nomor II/MPR/1993)

Hutt,Sherry,Elwood W. Jones, Martin E.Mc Allister,1992, Archaeological Resource Protection, Washington D.C: Preservation Press.

Indraningsih,J Ratna dkk, 1985 Laporan Penelitian Arkeologi di Daerah Calon Genangan Waduk Kedung Ombo, Jawa Tengah, Berita Penelitian Arkeologi No 31, Jakarta: Proyek Penelitian Purbakala Jakarta

Kusumohartonoı 8. M. (1993). Penelitian Arkeologi Dalam Konteks Pengembangan Sumberdaya Arkeologi. Berkala Arkeologii 13(2), 46-57. https:Ildoi.orglv0.30883ljba.vi3i2.576

Mundardjito, 1996. Pendekatan Integratif dan Partisipatif dalam Pelestarian Budaya, Jurnal Arkeologi Indonesia, Nomor 2 Maret. Jakarta: IAAI Pusat

Scovil, Gordon, dan Anderson, 1977. Guidelines for the Preparation of Statements of Environmental Impact on Archaeological Resources, dalam Schiffer,M.B dan G.J.Gumerman (ed.) Conservation Archaeology New York Academic Press 